\title{
Molekularna detekcija i fillogenijska analiza adenovirusa povezanog s fatalnom bolesti juvenilnih bradatih agama (Pogona vitticeps) u Hrvatskoj
}

Vladimir Savic ${ }^{*}$

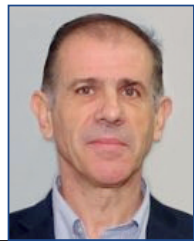

\section{Sažetak}

Australski su gušteri, bradate agame (Pogona vitticeps), vrlo popularni kućni ljubimci koji se uzgajaju u zatočeništvu $u$ brojnim zemljama, a međunarodna trgovina ove vrste guštera nije zanemariva. Bradate agame su osjetljive na infekciju adenovirusom agamida tipa 1 (BDAdv-1) čiji je uzročnik usko povezan s raznim kliničkim znacima poput: iznenadne smrti, letargije, slabosti, proljeva, dehidracije, anoreksije, zaostajanja u rastu i neuroloških simptoma koji nastaju zbog oštećenja jetara. Opisana je fatalna bolest dviju juvenilnih bradatih agama $u$ Hrvatskoj tijekom koje je detektirana infekcija adenovirusom. Osim slabosti, anoreksije, kaheksije i dehidracije, $u$ jedne agame je

bio naglašen opistotonus. U fecesu agama je postupkom lančane reakcije polimerazom dokazan adenovirus, dok je nukleotidnim sekvenciranjem i filogenijskom analizom nađena visoka podudarnost $\mathrm{s}$ BDAdv-1 izolatima iz bradatih agama u SAD-u, Austriji i Njemačkoj (>99,6 \%-100\%), ali i s BDAdv-1 iz slobodnoživućih bradatih agama u Australiji ( $>99,2 \%)$. Pokušaj izdvajanja virusa kroz dvije pasaže u pačjim embrijima ili deset pasaža u kokošjim embrijima nije dao pozitivan rezultat.

Ključne riječi: adenovirus, gmazovi, gušter, Pogona vitticeps, Agamid adenovirus 1, BDAdv-1, Hrvatska

\section{Uvod}

Adenovirusi predstavljaju vrlo veliku i raznoliku skupinu virusa izoliranih ili detektiranih u gotovo

svim glavnim razredima kralježnjaka. Najčešće se nalaze u pticama, gmazovima i šišmišima u kojima 
su i najraznovrsniji (Harrach i sur., 2019.). U rod Mastadenovirus ubrajamo adenoviruse koji se nalaze isključivo u sisavcima, slično kao i rod Aviadenovirus $\mathrm{u}$ kojem su isključivo adenovirusi podrijetlom iz ptica. Rod Ichtadenovirus uključuje samo jedan virus nađen u jesetri, dok novopredloženi rod Testadenovirus uključuje adenoviruse nađene za sada samo u nekim vrstama kornjača. U rodovima Siadenovirus i Atadenovirus svrstani su adenovirusi iz širokog spektra domaćina iz više razreda kralježnjaka (Harrach i sur., 2019., Anonymous, 2020.). Prvi detektirani atadenovirus je pačji adenovirus koji je uzročnik sindroma pada nesivosti (EDS) u kokoši (McFerran, 1979.). Atadenovirusi su potom detektirani i u preživačima, tobolčarima, gušterima, zmijama i kornjačama (Garcia-Morante i sur., 2016., Harrach i sur., 2019.). Svi adenovirusi detektirani u gušterima i zmijama pripadaju isključivo ovom rodu i pretpostavlja se da atadenovirusi vuku podrijetlo iz gmazova (Harrach, 2000., Farkas i sur., 2002.).

Centralna bradata agama (Pogona vitticeps) je australski gušter koji je zbog svojega izgleda, pitomosti, radoznalosti, dnevne aktivnosti, otpornosti i uspješnog razmnožavanja $\mathrm{u}$ zatočeništvu vrlo popularan među ljubiteljima kućnih ljubimaca (Christie, 1993.) i najčešći je gušter koji se drži u zatočeništvu (Raiti i sur., 2012.). Izvoz je ovog guštera iz Australije zabranjen, tako da postoji značajna industrija njegovog uzgoja u brojnim zemljama svijeta. Prva detekcija adenovirusa iz centralne bradate agame bila je iz kućnog ljubimca u SAD-u (Wellehan i sur., 2004.). Ovim istraživanjem po prvi je put postala dostupna nukleotidna sekvenca adenovirusa detektiranih $u$ guštera. Adenovirus je dobio oznaku BDAdv-1 prema engleskom nazivu za bradatu agamu (engl. bearded dragon), a kao sinonim se koristi i izraz agamid adenovirus 1. Novim prijedlogom Međunarodnog odbora za taksonomiju virusa (ICTV) ovaj virus se označava kao species Lizard atadenovirus B (Anonymous, 2020.). Ova vrsta adenovirusa detektirana je nakon SAD-a i u bradatim agamama u Austriji (Kübber-Heiss i sur., 2006.), Njemačkoj (Papp i sur., 2009., Schilliger i sur., 2016.), Ujedinjenom Kraljevstvu (Kubiak, 2013.), Australiji (Doneley i sur., 2014.) i Mađarskoj (Pénzes i sur., 2020.). Iako ne postoje službeni prikazi, u Genskoj se banci mogu naći sekvence BDAdv-1 dokazane $u$ bradatim agamama u Japanu. Kao i kod mnogih drugih virusnih infekcija gmazova, prava patogenost ovog virusa je nejasna i vjerojatno je povezana s dobi, čimbenicima okoliša i koinfekcijama. Vjeruje se da je BDAdv-1 odgovoran ili barem usko povezan s raznim kliničkim znacima poput: iznenadne smrti, letargije, slabosti, proljeva, dehidracije, anoreksije, zaostajanja u rastu i neuroloških simptoma koji nastaju zbog oštećenja jetara. Karakterističan je opistotonus kojeg se opisuje kao „stargazing" (gledanje u zvijezde) (Wellehan i sur., 2004., Kübber-Heiss i sur., 2006., Papp i sur., 2009., Parkin i sur., 2009., Doneley i sur., 2014., Schilliger i sur., 2016.). Brojne bradate agame mogu ostati asimptomatski kliconoše te zaraziti potomstvo (Marschang, 2011., Kubiak, 2013.).

Cilj je ovog rada detektirati, tipizirati i pokušati umnožiti adenovirus iz oboljelih bradatih agama u Hrvatskoj.

\section{Materijali i metode Opis slučaja}

Dvije juvenilne centralne bradate agame ( $P$. vitticeps), ženka i mužjak iz istog uzgoja, kupljene su u Hrvatskoj na izložbi egzotičnih životinja. Smještene su u optimalne uvjete primjerene dobi, ali već narednog dana agame su slabije jele 
i manje su bile aktivne. Nakon primjene potporne terapije nije došlo do oporavka, a nakon nekoliko dana pojavila se letargija, slabost, dehidracija i anoreksija u obje jedinke, a u ženke i neurološki simptomi u vidu opsitotonusa (slike 1 i 2). Prva je uginula ženka, a dan kasnije i mužjak. Od životinja su prikupljeni uzorci fecesa za laboratorijsko pretraživanje.

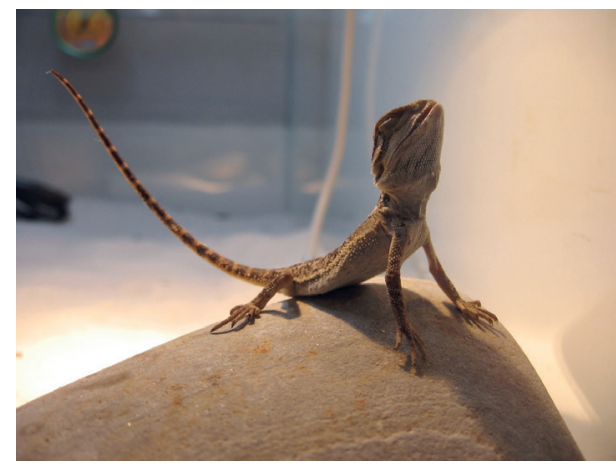

Slika 1. Ženka juvenilne bradate agame (Pogona vittices) s kaheksijom i naglašenim opistotonusom

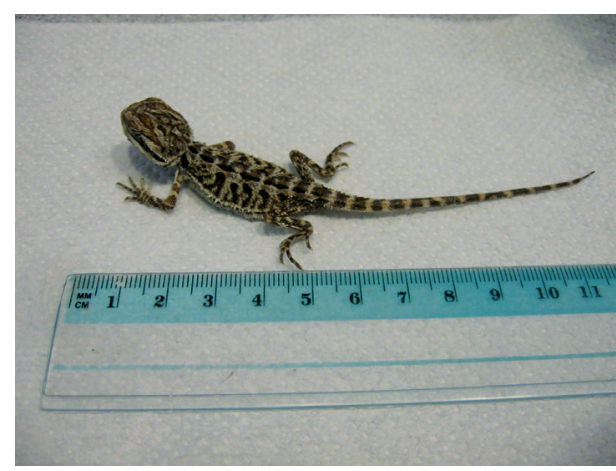

Slika 2. Mužjak juvenilne bradate agame (Pogona vittices) sa simptomima letargije i kaheksijom

\section{Molekularne metode}

Feces agama je homogeniziran $\mathrm{u}$ fiziološkoj otopini u omjeru 1:10 i pročišćen centifugiranjem na 2.000 okretaja u minuti tijekom 20 minuta.
Nadtalog je korišten za izdvajanje virusne DNK korištenjem komercijalnog kompleta High pure Viral Nucleic Acid Kit (Roche Applied Science, Njemačka) i prema uputama proizvođača.

Lančana reakcija polimerazom (PCR) za djelomičnu nukleotidnu sekvencu adenovirusne DNK polimeraze je učinjena prema Wellehanu i sur. (2004.) uz manje modifikacije. Za prvi PCR korištene su vanjske početnice koje daju proizvod od 556 parova baza, a za drugi (,nested“) PCR unutarnje početnice koje daju proizvod od 321 para baza. U oba PCR-a je korišteno po $5 \mu \mathrm{L}$ izdvojene DNK, odnosno proizvoda prvog PCR-a umjesto $2 \mu \mathrm{L}$, dok je za oba PCR-a korišten komplet GoTaq ${ }^{\circledR}$ Green MasterMix (Promega, SAD). PCR proizvod korištenjem unutranjih početnica je odvojen elektroforezom u $2 \%$-tnom gelu agaroze s dodatkom etidijevog bromida $(0,5 \mathrm{mg} / \mathrm{L}) \quad$ i vizualiziran pomoću ultraljubičastog svjetla. Dio gela sa specifičnim PCR proizvodom od 321 para baza je izrezan i pročišćen komercijalnim kompletom Wizard SV Gel and PCR Clean-Up System (Promega, SAD). Pročišćeni proizvod je korištenjem unutarnjih početnica na uređaju 3730XL DNK (Applied Biosystems, SAD) i pomoću kompleta BigDye v3.1 (Applied Biosystems, SAD) u oba smjera sekvenciran.

Nakon što su iz dobivenih sekvenci uklonjeni dijelovi koji odgovaraju korištenim početnicama, preostali dio nukleotidnih sekvenci je objedinjen i uređen pomoću računalnog programa ALIGN Plus 2.0. Genotipizacija i filogenijsko grupiranje dobivene nukleotidne sekvence je temeljeno na usporedbi s reprezentativnim sojevima adenovirusa kao i sa sekvencama dobivenim pretraživanjem Genske banke uporabom BLAST algoritma optimiziranim za traženje vrlo sličnih sekvenci tzv. megablast (http://www. ncbi.nlm.nih.gov). Pomoću računalnog 
programa MEGA7 korištena je filogenijska analiza najveće vjerojatnosti (Maximum likelihood phylogenetic analysis) (Kumar i sur., 2016.).

\section{Inokulacija kokošjih i pačjih embrija}

Nadtalog homogenata fecesa je pročišćen od bakterija korištenjem brizgaljke i filtra Filtropur S s porama promjera $200 \mathrm{~nm}$ (Sarstedt, Njemačka) $\mathrm{i}$ inokuliran po $0,1 \mathrm{~mL} u$ alantoisnu šupljinu tri 10-dnevna embrija. Embriji su inkubirani pri $37{ }^{\circ} \mathrm{C}$ narednih 4 do 6 dana uz svakodnevnu provjeru vitalnosti prosvjetljavanjem. Nakon inkubacije embriji su pothlađeni na 4 ${ }^{\circ} \mathrm{C}$ preko noći, a potom je $\mathrm{u}$ sterilnim uvjetima prikupljena alantoisna tekućina. Prema opisanom postupku dio alantoisne tekućine je inokuliran $\mathrm{u}$ tri embrija, a ostatak je pohranjen na $-20{ }^{\circ} \mathrm{C}$. Postupak je ponavljan 10 puta u kokošjim embrijima ili dva puta $u$ pačjim embrijima. Svi uzorci alantoisne tekućine su testirani na prisutnost nukleotidne sekvence adenovirusne DNK polimeraze postupkom opisanim u molekularnim metodama.

\section{Rezultati}

Postupkom PCR-a u uzorcima fecesa obje jedinke dokazana je nukleotidna sekvenca adenovirusne DNK polimeraze (slika 3) čime je potvrđena pristutnost adenovirusa $\mathrm{u}$ fecesu oboljelih agama. Nukleotidnim sekvenciranjem PCR proizvoda u oba uzorka je dobivena identična sekvenca zakojujefilogenijskom analizom utvrđeno da odgovara sekvenci

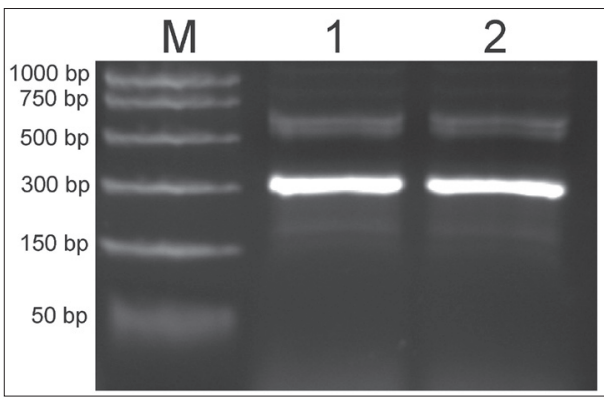

Slika 3. Elektroforeza u gelu proizvoda umreženog (.nested“) PCR-a specifičnih za adenovirus (321 baznih parova) dobivenih iz fecesa bradatih agama (Pogona vitticeps) u Hrvatskoj. $M=$ marker, 1=ženka, 2=mužjak. Lijevo su označene veličine unutar markera

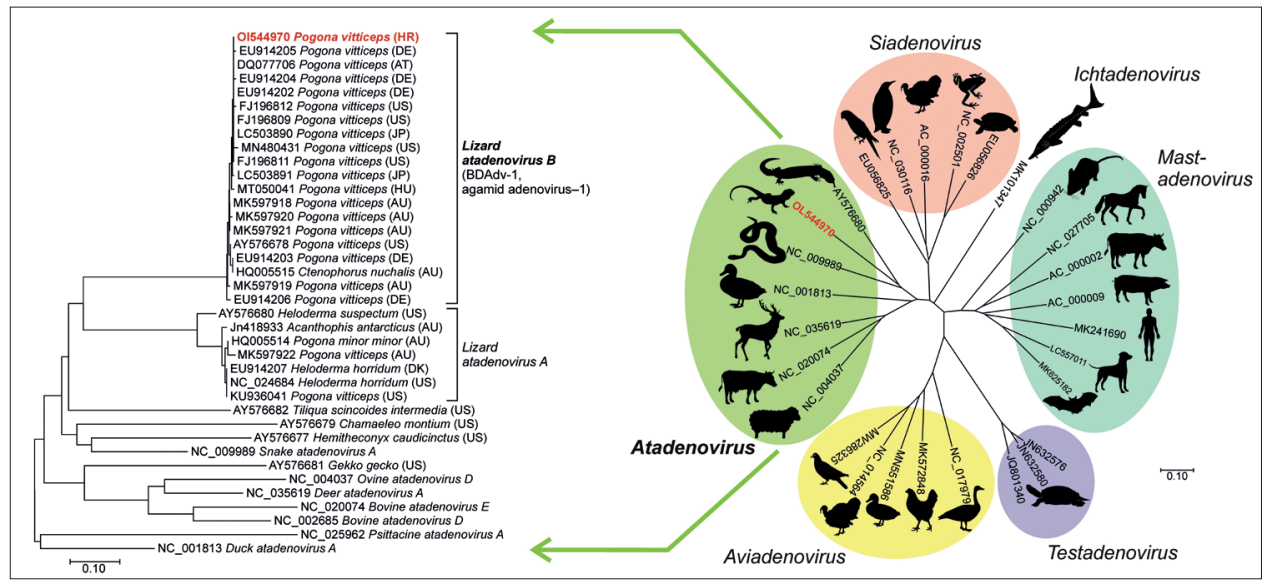

Slika 4. Prikaz filogenijske analize adenovirusa (gen DNK polimeraze) detektiranog u bradatim agamama (Pogona vitticeps) u Hrvatskoj. Radijalno stablo (desno) prikazuje filogenijsku analizu svih rodova adenovirusa. Uglato stablo (lijevo) prikazuje filogenijsku analizu unutar roda Atadenovirus. Adenovirus detektiran u bradatih agama u Hrvatskoj je u oba stabla označen podebljano i crvenom bojom 
BDAdv-1 (agamid adenovirus-1), tj. da pripada rodu Atadenovirus, vrsti Lizard atadenovirus B (slika 4). Nukleotidna sekvenca je pohranjena u Genskoj banci pod pristupnim brojem OL544970. Pretraživanjem vrlo sličnih sekvenci $u$ Genskoj banci (megablast) pronađeno je svega 20 sekvenci koje su se podudarale s hrvatskom sekvencom od 97,79 do $100 \%$. Najveća podudarnost hrvatske sekvence BDAdv-1 nađena je $s$ više nukleotidnih sekvenci BDAdv-1 iz SAD-a, Austrije, Njemačke $(>99,6 \%)$, ali i sa sekvencama virusa detektiranih u slobodnoživućim bradatim agamama u Australiji ( $>99,2 \%$ ). Jedna sekvenca BDAdv-1 iz SAD-a imala je $100 \%$-tnu podudarnost s hrvatskom sekvencom.

U prikupljenim alantoisnim tekućinama inokuliranih kokošjih i pačjih embrija nije dokazana prisutnost nukleotidne sekvence adenovirusne DNK polimeraze.

\section{Rasprava}

Prvi zapis oadenovirusu u australskoj agami potječe iz 1980-ih kada je elektronskom mikroskopijom detektiran u krijumčarenoj istočnoj bradatoj agami (Pogona barbata) zaplijenjenoj na Novom Zelandu. Odrasla ženka po zaplijeni nije jela nekoliko dana, zatim je normalno uzimala hranu tijekom tri tjedna da bi ponovo odbijala hranu i ubrzo uginula. Iako je bila dobre tjelesne kondicije, nađena su oštećenja jetre s eozinofilnim intracelularnim uklopinama $\mathrm{u}$ brojnim hepatocitima (Julian i Durham, 1982.). Hyndman i sur. (2019.) dokazuju upravo BDAdv-1 u slobodnoživuće $P$. barbata, a osim ove iznimke, Hyndman i Shilton (2011.) su detektirali ovaj virus i u slobodnoživućoj centralnoj mrežastoj agami (Ctenophorus nuchalis) s oštećenjima jetre poput onih u istočnoj bradatoj agami zaplijenjenoj u Novom Zelandu. Iako su sve tri spomenute vrste agama, centralna bradata $(P$. vitticeps), istočna bradata ( $P$. barbata) $i$ mrežasta (C. nuchalis) agama autohtone australske vrste, BDAdv-1 je u najvećem broju, gotovo isključivo detektiran u centralne bradate agame. Razlog ovome najverojatnije nije njihova veća osjetljivost prema ovom virusu, već njihov veliki broj u uzgojima diljem svijeta gdje se drže kao ljubimci pa im se stoga i posvećuje veća pozornost, a i pristupačniji su za laboratorijska testiranja. Misli se da je BDAdv-1 ukorijenjen $\mathrm{u}$ uzgojima ovog guštera u SAD-u (Mitchell, 2007.), a tako je i u ostalim uzgojima diljem svijeta $\mathrm{s}$ tim da infekcija ne bude zamijećena, prepoznata ili pak ne bude laboratorijski potvrđena i zabilježena. Ovome u prilog ide i nalaz BDAvd-1 u centralne bradate agame u Hrvatskoj koji je u analiziranom dijelu genoma identičan jednom BDAdv-1 iz SAD-a. Slično ovome, Kubiak (2013.) smatra da je povećana prevalencija ovog virusa u uzgojima u Ujedinjenom Kraljevstvu posljedica uvoza novog genetskog materijala iz SAD-a u cilju dobivanja novih uzgojnih varijanti centralne bradate agame. Kako širok izbor genetskih morfova boja postaje dostupan putem kontroliranog uzgoja u privatnim zbirkama, potražnja za bradatima agamama kao egzotičnim kućnim ljubimcima općenito nastavlja rasti u svijetu pa i u Hrvatskoj. Ne izuzimajući mogućnost krijumčarenja agama iz trećih zemalja kao način unosa virusa, pristupanjem zajedničkom EU tržištu u Hrvatskoj je povećana mogućnost unosa BDAdv-1 slobodnom trgovinom unutar EU. Našim veterinarima proteklih su godina egzotični kućni ljubimci, uključujući i gmazove, sve češći pacijenti (Lukač i sur., 2013., Efendić i sur., 2019.). Stoga predmnijevamo da je ovaj rad značajan doprinos našim veterinarima $\mathrm{u}$ prepoznavanju infekcije gmazova adenovirusima, posebno bradatih agama kao sve češćih kućnih ljubimaca 
kao i prikazu mogućnosti laboratorijske dijagnostike ovih infekcija. Osim toga, u Genskoj banci je dostupan vrlo mali broj nukleotidnih sekvenci za BDAdv-1 tako da ovo istraživanje, koje je rezultiralo javno dostupnom hrvatskom sekvencom BDAdv-1, predstavlja doprinos međunarodnoj znanstvenoj zajednici koja se bavi istraživanjem adenovirusa.

Važnost izdvajanja i umnožavanja virusa u znanstvene i druge svrhe ne treba posebno naglašavati. Papp i sur. (2009.) uspjeli su izdvojiti i umnožiti Lizard Atadenovirus $A$ iz tri guštera roda Heloderma od ukupno 26 jedinki iz različitih rodova guštera koji su bili pozitivni testom PCRa. Među PCR pozitivnim gušterima bile su i centralne bradate agame i smaragdno zeleni varan (Varanus prasinus) iz kojih nisu uspjeli izdvojiti virus. Virus je iz guštera roda Heloderma izdvojen i umnožen na linijskoj staničnoj kulturi srca iguane. $\mathrm{U}$ ovom istraživanju pokušali smo izdvojiti Lizard Atadenovirus B (BDAdv-1) u pačjim i kokošjim embrijima budući da se atadenovirus uzročnik sindroma pada nesivosti može izdvojiti i umnožiti u visokom titru u pačjim embrijima (Higashihara i sur., 1983.). S obzirom na ograničenu dostupnost pačjih embrija, učinjene su dvije pasaže, dok je dobra dostupnost kokošjih embrija omogućila deset pasaža. Budući da su alantoisne tekućine u testu PCR-om dale negativan rezultat, zaključujemo da se BDAdv-1 opisanim postupkom ne može izdvojiti u pačjim ili kokošjim embrijima.

Prema našim spoznajama ovo je $u$ Hrvatskoj prvi dokaz adenovirusa $u$ bradatih agama i gmazova općenito.

\section{Literatura}

1. Anon. (2020): ICTV. Virus Taxonomy-2020 Release. Available online: https:/talk.ictvonline.org/ taxonomy/ (accessed on 25 December 2021).

2. CHRISTIE, B. (1993): Captive breeding and reproduction of the in land bearded dragon. Captive Breeding Mag. 1, 20-23.
3. DONELEY, R. J., K. N. BUCKLE and L. HULSE (2014): Adenoviral infection in a collection of juvenile inland bearded dragons (Pogona vitticeps). Aust. Vet. J. 92, 41-45. 10.1111/avj.12136

4. EFENDIĆ, M., M. SAMARDŽIJA, H. CAPAK, G BAČIĆ, I.ŽURAŽAJA, V. MAGAŠ and N. MAĆEŠIĆ (2019): Induction of the oviposition in bearded dragon (Pogona vitticeps) with postovulatory egg retention (dystocia) - a case report. Vet. arhiv 89, 131-142. 10.24099/vet.arhiv.0300

5. FARKAS, S. L., M. BENKŐ, P. ÉLŐ, K. URSU, Á DÁN, W. AHNE and B. HARRACH (2002): Genomic and phylogenetic analyses of an adenovirus isolated from a corn snake (Elaphe guttata) imply a common origin with members of the proposed new genus Atadenovirus. J. Gen. Virol. 83, 2403-2410. 10.1099/0022-1317-83-10-2403

6. GARCIA-MORANTE, B., J. J. PÉNZES, T. COSTA, J MARTORELL and J. MARTINEZ (2016): Hyperplastic stomatitis and esophagitis in a tortoise (Testudo graeca) associated with an adenovirus infection. J. Vet. Diagn. Investig. 28, 579583. $10.1177 / 1040638716659903$

7. HARRACH, B. (2000): Reptile adenoviruses in cattle? Acta Vet. Hung. 48, 485-490. 10.1556/004.48.2000.4.11

8. HARRACH, B., Z. L. TARJAN and M. BENKO (2019): Adenoviruses across the animal kingdom: A walk in the zoo. FEBS Lett. 593, 3660-3673. 10.1002/1873-3468.13687

9. HIGASHIHARA, M., S. TAKAI, A. HIDAKA, T. HOUDATSU, M. HIRUMA, Y. WATANABE and M. MATUMOTO (1983): Isolation of the virus of egg drop syndrome 1976 (EDS -'76) in a Japanese outbreak. Jpn. J. Vet. Sci. 45, 603-612. 10.1292/ jvms1939.45.603

10. HYNDMAN, T. H., J. G. HOWARD and R. J. DONELEY (2019): Adenoviruses in free-ranging Australian bearded dragons (Pogona spp.). Vet. Microbiol. 234, 72-76. 10.1016/j.vetmic.2019.05.014

11. HYNDMAN, T. and C. M. SHILTON (2011): Molecular detection of two adenoviruses associated with disease in Australian lizards. Aust. Vet. J. 89, 232-235. 10.1111/j.1751-0813.2011.00712.x

12. JULIAN, A. F. and P. J. K. DURHAM (1982): Adenoviral hepatitis in a female bearded dragon (Amphibolurus barbafus). N. Z. Vet. J. 30, 59-60. 10.1080/00480169.1982.34880

13. KÜBBER-HEISS, A., V. BENETKA, T. FILIP, G. BENYR, F. SCHILCHER, C. PALLAN and $\mathrm{K}$. MÖSTL (2006): First detection of an adenovirus infection in a bearded dragon (Pogona vitticeps) in Austria. WTM 93, 68-72. (In German).

14. KUBIAK, M. (2013): Detection of agamid Adenovirus-1 in clinically healthy bearded dragons (Pogona vitticeps) in the UK. Vet. Rec. 172, 475. 10.1136/vr.101087

15. KUMAR, S., G. STECHER and K. TAMURA (2016): MEGA7: Molecular evolutionary genetics analysis version 7.0 for bigger datasets. Mol. Biol. Evol. 33, 1870-1874. 10.1093/molbev/msw054 
16. LUKAČ, M., D. HORVATEK TOMIĆ and E. PRUKNER-RADOVČIĆ (2013): Findings of Devriesea agamarum associated infections in spiny-tailed lizards (Uromastyx sp.) in Croatia. J. Zoo. Wildl. Med. 44, 430-434. 10.1638/2012-0100R.1

17. MARSCHANG, R. E. (2011): Viruses infecting reptiles. Viruses 3, 2087-2126. 10.3390/v3112087

18. McFERRAN, J. B. (1979): Egg drop syndrome, 1976 (EDS'76). Vet. Q. 1, 176-180. 10.1080/01652176.1979.9693744

19. MITCHELL, M. A. (2007): Biology and medicine of bearded dragons. NAVC Proceedings 21, 1592-1594.

20. PAPP, T., B. FLEDELIUS, V. SCHMIDT, G. L. KAJÁN and R. E. MARSCHANG (2009): PCRsequence characterization of new adenoviruses found in reptiles and the first successful isolation of a lizard adenovirus. Vet. Microbiol. 134, 233-240. 10.1016/j.vetmic.2008.08.003

21. PARKIN, D. B., L. L. ARCHER, A. L. CHILDRESS and J. F. WELLEHAN (2009): Genotype differentiation of agamid adenovirus 1 in bearded dragons (Pogona vitticeps) in the USA by hexon gene sequence. Infect. Genet. Evol. 9, 501-506. 10.1016/j. meegid.2009.01.010
22. PÉNZES, J. J., L. SZIROVICZA and B. HARRACH (2020): The complete genome sequence of bearded dragon adenovirus 1 harbors three genes encoding proteins of the C-type lectin-like domain superfamily. Infect. Genet. Evol. 83, 104321. 10.1016/j.meegid.2020.104321

23. RAITI, P. (2012): Husbandry, diseases, and veterinary care of the bearded dragon (Pogona vitticeps). JHMS 22, 117-131. 10.5818/1529-9651-22.3.117

24. SCHILLIGER, L., V. MENTRE, R. E. MARSCHANG, A. NICOLIER and B. RICHTER (2016): Triple infection with agamid adenovirus 1, Encephaliton cuniculi-like microsporidium and enteric coccidia in a bearded dragon (Pogona vitticeps). Tierarztl. Prax. Ausg. K. Kleintiere. Heimtiere. 44, 355-358. (In German). 10.15654/TPK-150790

25. WELLEHAN, J. F., A. J. JOHNSON, B. HARRACH, M. BENKŐ, A. P. PESSIER, C. M. JOHNSON, M. M. GARNER, A. CHILDRESS and E. R. JACOBSON (2004): Detection and analysis of six lizard adenoviruses by consensus primer PCR provides further evidence of a reptilian origin for the atadenoviruses. J. Virol. 78, 13366-13369. 10.1128/ JVI.78.23.13366-13369.2004

\section{Molecular detection and phylogenetic analysis of adenovirus associated with fatal disease of juvenile bearded dragons (Pogona vitticeps) in Croatia}

Vladimir SAVIĆ, DVM, PhD, Assistant Professor, Scientific Advisor, Poultry Centre, Croatian Veterinary Insitute, Zagreb, Croatia

Bearded dragons (Pogona vitticeps) are popular pets bred in captivity in numerous countries, with considerable international trade of this species. Bearded dragons are sensitive to bearded dragon adenovirus 1 (BDAdv-1) which causes or is closely associated with various clinical symptoms including sudden death, lethargy, weakness, diarrhoea, dehydration, anorexia, retarded growth, and neurological symptoms resulting from liver damage. A fatal disease of two juvenile bearded dragons in Croatia during which adenovirus was detected is described. Weakness, anorexia, cachexia and dehydration were present in the male and the female bearded dragon, in addition to marked opistothonus in the female. The adenovirus was detected by PCR while nucleotide sequencing and phylogenetic analysis revealed high homology with BDAdv-1 strains from bearded dragons in the United States, Austria and Germany (>99.6-100\%), but also with BDAdv-1 from free-ranging Australian bearded dragons (>99.2\%). An attempt to isolate the virus through two passages in duck embryos or ten passages in chicken embryos did not yield a positive result.

Key words: adenovirus; reptiles; lizard; Pogona vitticeps; Agamid adenovirus 1; BDAdv-1; Croatia 